\title{
Appraisal of Awareness among Dental Orthodontic Staffs Staff about Universal Precaution at Selected Dental Clinics, Saudi Arabia
}

\author{
Dr. Alhassan Khalid Alsaiari ${ }^{1}$, Dr. Suhail Abdulrahman Alamoudi ${ }^{2}$ \\ ${ }^{1,2}$ General Dentist, Dental Specialty Center, King Fahad Hospital- (KFHM)-Al-Medina
}

\begin{abstract}
Background: Awareness among Orthodontic Staff about Universal Precaution requires being highly valued and practices by all the health care practitioners, despite the fact that decisive staff development in the prevention of Infection. Objective: To Evaluation of Awareness of Orthodontic Staff about Dental Site Infection among Orthodontic Staff at the Selected Dental ClinicsSaudi Arabia. Method: A cross-sectional survey was conducted at the Selected Dental Clinics-Saudi Arabia. The assessment tool was consists of 16 items self-administered questionnaire was provided to 150 Orthodontic Staff in the research setting based on their area of their specialties to assess their level of evaluation of Awareness of Orthodontic Staff about Personal Protective Equipments. Results: The findings of the current study showed the level of awareness of Universal Precaution was significantly associated with many variables (Table .1). The findings of the current study showed than more than two third $(90.0 \%) *$ of the respondents were very aware of Universal Precaution with statistically significantly difference in relation to the aspect of Adequate information about how to prevent Infection. Moreover, it was found that Dental staff' had high level of awareness (87.5\%) in relation to Senior management is accountable for ensuring that healthcare personnel, including licensed and no licensed personnel, are adequately trained and competent to perform their job responsibilities towards Infection. Furthermore, majority of the participants (87.5\%) Personnel from the IPC program, the laboratory, and information technology departments are responsible for ensuring that systems are in place to support the surveillance program of prevention of Dental Site Infection. Conclusions: The current study results revealed that there were a high levels of awareness among Dental staff' towards Universal Precaution within the study setting.
\end{abstract}

Keywords: Dental staff; Awareness \& Universal Precaution (UP)

\section{Introduction}

Universal Precautions considering as a healthcare-associated infections. The target of this document is to highlight practical recommendations in a concise format designed to (UP) at acute care hospitals in implementing and prioritizing their Dental site infection (UP) prevention efforts. This document updates "Strategies to Prevent Dental Site Infections in Acute Care Hospitals published in 2008. Universal Precaution was initially developed in 1987 by the Centers for Disease Control and Prevention in the United States and in 1989 by the Bureau ofCommunicable Disease Epidemiology in Canada. The Precautions include specific recommendationsfor use of gloves,gowns, masks, and protective eyewearwhen contact with blood or body secretions containing blood is anticipated. (Christian, et al., 2004)

Health care personnel in particular Dental staff' is at risk of acquiring infection through personal exposure to infectious diseases. The minority studies have reported on Dental staff' adherence towards Personnel Protective Equipments and reported lack of adequate practices in relation to compliance towards the personnel protective equipments. (Peiris, et al., 2003).

Exposure to particular health hazards are expected to influence definite high-risk for all the health care providers. All the health care workers especially the Orthodontic Staff who are working in Dental units and Operation Theater are more required to have a reason of a better understanding in adherence with PPE usage which is significant as it provides an assessment of the efficacy of assemble preventative strategies. This could then (UP) at to recognize the preventive variables which are likely to improve the compliance and decrease the risk of infection. Then, it is able to integrate these preventative approaches into the strategies of health care setting. (Loeb, et al., 2004 \& Ofner, et al., 2003)

Universal Precaution is the only approach so that all these infections could be prevented. Inadequate experience of Orthodontic Staff in performing invasive procedures, they are at particular risk of exposure to blood-borne pathogens (Chopra, et al., 2008). Dental staff' should have reasonable awareness and performance in relation to adherence to personnel protective equipments. Additionally, Low \& McGeer (2003), reported that dedicated training must be conducted before a Orthodontic Staff caring for any patient procedure particularly the ones concerning sharp devices. Physicians' compliance towards the Universal Precaution has been reported to be with low rate. (Spring, 2007).

Non adherence to Universal Precaution by the health care providers, statistics reported by the Central Register of Occupational Diseases in Poland indicates that among 314 new cases of occupational diseases in HCWs in 2005, HBV and $\mathrm{HCV}$ represented $42.6 \%$ of all cases.9 Despite the substantial reduction in $\mathrm{HBV}$ infection since vaccination was introduced in 1989, the incidence of HCV hepatitis in Poland is still on the increase in this occupational group. Chaovavanich, et al., (2004) \& Siegel, et al., (2007). 


\section{International Journal of Science and Research (IJSR) \\ ISSN (Online): 2319-7064}

Index Copernicus Value (2013): 6.14 | Impact Factor (2015): 6.391

Furthermore, universal precaution consciousness education has not been prominent among health care workers especially the category of Dental staff, particularly in developing countries. To the best of our awareness and standardized practices with PPE among Dental staff. We, therefore, conducted this study to assess the levels of awareness towards Universal Precaution among Orthodontic Staff during their duties at the Selected Dental Clinics, Saudi Arabia.

\section{Participants and Methods}

The participants were selected from the Orthodontic Staff at Selected Dental Clinics. After signing an informed written consent form, the questionnaire was given to each participant. Before administration of the questionnaire, the purpose of the study was explained to each respondent and confidentiality of the information assured.

The research was carried out the authors who were appropriately trained in administering the informed consent and the self-report questionnaire to the health care workers. In this cross-sectional study, a structured questionnaire prepared by the authors, was administered to the participants. 16-itemes self-administered structured questionnaire about awareness and awareness of Universal Precaution in the health care system was devised de novo and tested. It included a full range of response options, designed to identify the dental restoratives' level of awareness towards Universal Precaution in the selected setting. Prior to distribution of the questionnaire, a pilot study was done on a selective group of health care workers who were asked to fill out the questionnaire and return it back with their comments and criticism. Minor changes were then made to the final instrument.
The initial part of the questionnaire consisted of demographic information such as occupation, age, gender, and the marital status. The second part of the questionnaire comprised of questions regarding their awareness dental restoratives' level of awareness towards Universal Precaution in the selected setting. This part also assessed awareness of policies regarding universal precautions, availability of protective equipments and measures how they value the use of protective equipments. It took approximately 15 minutes to complete each questionnaire.

The level of aware towards Universal Precaution by examining questions about: use of protective barriers such as gloves and gown, mask and protective goggles. A score of "1" was (UP) for a correct answer and " 0 " for an incorrect answer. A health care worker who obtained a total score of " 5 " was considered "very awareness able;" "4 or 3" "somewhat aware;" and "1 or 0" "not awareness able."

The Universal Precaution required by the health care worker include N95 mask, Dental mask, paper mask, protective goggles, gowns, gloves, and (UP)r cover, among other equipments. These vary depending on the duty performed by the health care provider. If less than half of the personal protective equipment identified by the particular health care worker was provided, then provision was considered "inadequate." If more than half of the protective equipment identified by the participants was provided, then provision was considered "adequate."

The data were coded and analyzed by SPSS ${ }^{\circledR}$ for Windows ${ }^{\circledR}$ ver. 12.0. Strict confidentiality was maintained. All the data were stored in computers at a secured location, with access provided only to the researchers involved in the study. The $\chi^{2}$ test was used to test association between categorical variables. A p value $<0.05$ (two-tailed) was considered statistically significant

\section{Results}

Table 1: Percentage of the Level of Awareness among Orthodontic Staff about Universal Precaution at Selected Dental Clinics, Saudi Arabia

\begin{tabular}{|c|c|c|c|}
\hline \multicolumn{4}{|c|}{ Level of Awareness Among Orthodontic Staff about Universal Precaution(\%) Variable } \\
\hline & \begin{tabular}{|c|c|} 
Not \\
Aware
\end{tabular} & $\begin{array}{c}\text { Somewhat } \\
\text { Aware }\end{array}$ & $\begin{array}{c}\text { Very } \\
\text { Aware }\end{array}$ \\
\hline \multicolumn{4}{|c|}{$\begin{array}{l}\text { Senior management is responsible for ensuring that the healthcare system supports an infection prevention and control (IPC) program } \\
\text { that effectively prevents healthcare-associated infections ((UP)s) and the transmission of (UP) of epidemiologically important pathogens }\end{array}$} \\
\hline $\begin{array}{l}\text { Senior management is accountable for ensuring that an adequate number of trained personnel to } \\
\text { avoid (UP) to the IPC program and adequate staffing of other departments that play a key role in } \\
\text { (UP) prevention (eg, environmental services) }\end{array}$ & $\left(\begin{array}{c}60 \\
(40.0 \%)\end{array}\right.$ & $5(3.4 \%)$ & $85(57.0 \%)^{*}$ \\
\hline $\begin{array}{c}\text { Direct healthcare providers (such as physicians, nurses, aides, and therapists) and ancillary } \\
\text { personnel (such as environmental service are responsible for ensuring that appropriate IPC } \\
\text { practices are used at all times (including hand hygiene, standard and isolation precautions, and } \\
\text { cleaning and disinfection of equipment and the environment) }\end{array}$ & $\begin{array}{c}23 \\
(15.3 \%)\end{array}$ & $7(4.7 \%)$ & $\begin{array}{c}120 \\
(80.0 \%) * *\end{array}$ \\
\hline $\begin{array}{l}\text { PC leadership is responsible for ensuring that an active program to identify (UP)s is } \\
\text { implemented, that (UP) data are analyzed and regularly provided to those who can use the } \\
\text { information to improve the quality of care (eg, unit staff, clinicians, and hospital } \\
\text { administrators), and that evidence-based practices are incorporated into the program }\end{array}$ & $\begin{array}{c}18 \\
(12.0 \%)\end{array}$ & $14(9.3 \%)$ & $\begin{array}{c}118 \\
(78.7 \%) * *\end{array}$ \\
\hline $\begin{array}{l}\text { Senior and unit leaders are accountable for ensuring that appropriate training and educational } \\
\text { programs to prevent (UP) are developed and provided to personnel, patients, and families }\end{array}$ & $\begin{array}{c}7 \\
(3.5 \%) \\
\end{array}$ & $20(10.0 \%)$ & $\begin{array}{c}173 \\
(86.5 \%) \\
\end{array}$ \\
\hline $\begin{array}{l}\text { Senior management is accountable for ensuring that healthcare personnel, including licensed and } \\
\text { no licensed personnel, are adequately trained and competent to perform their job responsibilities } \\
\text { towards Dental Site Infection }\end{array}$ & $\begin{array}{l}5 \\
(2.5 \%)\end{array}$ & $20(10.0 \%)$ & $\begin{array}{c}175 \\
(87.5 \%)\end{array}$ \\
\hline
\end{tabular}

Volume 6 Issue 1, January 2017 www.ijsr.net

Licensed Under Creative Commons Attribution CC BY 


\section{International Journal of Science and Research (IJSR) \\ ISSN (Online): 2319-7064}

Index Copernicus Value (2013): 6.14 | Impact Factor (2015): 6.391

\begin{tabular}{|c|c|c|c|}
\hline Adequate information about how to prevent Dental site infection & 4 & $16(8.0 \%)$ & $(90.0 \%)$ \\
\hline $\begin{array}{c}\text { Personnel from the IPC program, the laboratory, and information technology departments are } \\
\text { responsible for ensuring that systems are in place to support the surveillance program of } \\
\text { prevention of Dental Site Infection }\end{array}$ & $\begin{array}{c}7 \\
(3.5 \%)\end{array}$ & $20(10.0 \%)$ & $\begin{array}{c}173 \\
(86.5 \%)\end{array}$ \\
\hline \multicolumn{2}{|c|}{ Significantly different: *p<0.0001; †p<0.01 } \\
\hline \multicolumn{2}{|c|}{}
\end{tabular}

The level of awareness of Universal Precaution was significantly associated with many variables (Table .1). The findings of the current study showed than more than two third $((90.0 \%) *$ of the respondents were very aware of Universal Precaution with statistically significantly difference in relation to the aspect of Adequate information about how to prevent Infection. Moreover, it was found that Dental staff' had high level of awareness (87.5\%) in relation to Senior management is accountable for ensuring that healthcare personnel, including licensed and no licensed personnel, are adequately trained and competent to perform their job responsibilities towards Infection. Furthermore, majority of the participants $(87.5 \%)$ Personnel from the IPC program, the laboratory, and information technology departments are responsible for ensuring that systems are in place to support the surveillance program of prevention of Dental Site Infection.

\section{Discussion}

The findings of the current study showed the level of awareness of Universal Precaution was significantly associated with many variables (Table .1). The findings of the current study showed than more than two third $(90.0 \%) *$ of the respondents were very aware of Universal Precaution with statistically significantly difference in relation to the aspect of Adequate information about how to prevent infection. Moreover, it was found that Dental staff' had high level of awareness $(87.5 \%)$ in relation to Senior management is accountable for ensuring that healthcare personnel, including licensed and no licensed personnel, are adequately trained and competent to perform their job responsibilities towards Infection. Furthermore, majority of the participants $(87.5 \%)$ Personnel from the IPC program, the laboratory, and information technology departments are responsible for ensuring that systems are in place to support the surveillance program of prevention of Dental Site Infection.

Our survey found gaps in awareness and adherence with recommended PPE use for influenza control across all types of dental staff with restorative specialty. This survey had a high overall response rate $(91.5 \%)$ and included respondents at the study setting. Significant variability in adherence was seen across the participants' awareness toward the use of PPE. Conviction that PPE adherence was inconvenient was associated with decreased odds of self-reported high adherence. However, perception that a supervisor would reprimand non adherence significantly increased the odds of self-reported adherence.

Despite the fact that infection prevention and control practices can significantly improve patient outcomes at Dental Unit adherence with these practices is generally high.
In our survey of dental staff with restorative specialty, majority of the participants $(87.5 \%)$ replied that they were adequacy of protective equipments within the current research setting. Majority of participants $(80 \%)$ reported that they were positively in relation to value of adherence towards personnel protective equipments.

This self-reported adherence rate likely overestimates actual adherence. Henry et al, (2012) demonstrated that point estimates of self-reported adherence with all barrier precautions with the exception of gloves. Furthermore, the current study findings is consistent with the reported results of the study carried out by, O'Boyle et al.,(2011) found that the correlation between reported and observed adherence with hand-washing recommendations among dentists was quite low $(\mathrm{r}-.22)$. To overcome this overestimation, respondent reports regarding their colleagues adherence with expected practices have been used as a surrogate measure for actual adherence .toward PPE. Using this measure, we would estimate that adherence in our study is approximately $47 \%$. The fact that $(80 \%)$ of respondents felt they could improve their use of PPE confirms that they were aware that their adherence is suboptimal.

Little is known about how HCWs are currently using recommended barrier precautions to prevent spread of influenza and other respiratory viruses, or the factors that influence adherence. Identified influences on adherence to best practice guidelines have included awareness, attitude, belief, and behavioral factors Predictors of PPE use Awareness' of correct PPE, age, and race were not significantly associated with reported PPE adherence in simple logistic as showed in (Table 1). Orthodontic Staff role, marital status, and specific beliefs about PPE use and efficacy were found to be significant predictors of high levels of adherence with PPE in both simple and multivariable logistic on analyses.

Majority of respondents reported a belief that PPE use would protect them and their patients, respectively, from getting influenza. Although this belief is plausible, given Centers for Disease Control and Prevention recommendations for PPE use, as we have mentioned, it is not supported by evidence from randomized clinical trials. Further, neither did this belief seem to influence behavior nor did it translate to similarly high levels of awareness regarding recommendations. In fact, a large proportion of our respondents also demonstrated important awareness gaps. This current study findings $\mathrm{s}$ congruent with the results carried out by Sandrock \& Stollenwerk (2008) , who reported that, more than $75 \%$ of respondents were unable to identify the group of precautions expected to confer appropriate protection from infection. This awareness gap suggests that some dentists may be unaware that they are

\section{Volume 6 Issue 1, January 2017} www.ijsr.net 


\section{International Journal of Science and Research (IJSR) \\ ISSN (Online): 2319-7064}

Index Copernicus Value (2013): 6.14 | Impact Factor (2015): 6.391

inadequately protecting themselves and their patients. At least half of our respondents reported that complying with recommended PPE was inconvenient. Inconvenience, in turn, was predictive of poorer adherence.

\section{Acknowledgment}

Appreciation is hereby extended to all the participants for the statistical analysis of the data.

\section{Conflicts of Interest}

None declared.

\section{References}

[1] Martin LS, McDougal JS, Loskoski SL. Disinfection and inactivation of the human $\mathrm{T}$ lymphotropic virus type III/Lymphadenopathy-associated virus. J Infect Dis 1985;152(2):400-3.

[2] McDougal JS, Martin LS, Cort SP, Mozen M, Heldebrant CM, Evatt BL. Thermal inactivation of the acquired immunodeficiency syndrome virus, human $\mathrm{T}$ lymphotropic virus-III/lymphadenopathy-associated virus, with special reference to antihemophilic factor. J Clin Invest 1985;76(2):875-7.

[3] Beltrami EM, Williams IT, Shapiro CN, Chamberland ME. Risk and management of blood-borne infections in health care workers. Clin Microbiol Rev 2000;13(3):385-407.

[4] Gerberding JL. Incidence and prevalence of human immunodeficiency virus, hepatitis B virus, hepatitis C virus, and cytomegalovirus among health care personnel at risk for blood exposure: final report from a longitudinal study. J Infect Dis 1994;170(6):1410-7.

[5] Ruben FL, Norden CW, Rockwell K, Hruska E. Epidemiology of accidental needle-puncture wounds in hospital workers. Am J Med Sci 1983;286(1):26-30.

[6] Pruss-Ustun A, Rapiti E, Hutin Y. Estimation of the global burden of disease attributable to contaminated sharps injuries among health-care workers. Am J Ind Med 2005;48(6):482-90.

[7] Khuri-Bulos NA, Toukan A, Mahafzah A, et al. Epidemiology of needlestick and sharp injuries at a university hospital in a developing country: a

[8] Wang FD, Chen YY, Liu CY. Analysis of sharpedged medical-object injuries at a medical center in Taiwan. Infect Control Hosp Epidemiol 2010;21(10):656-8.

[9] Pruss-Ustun A, Rapiti E, Hutin Y. Sharp injuries: global burden of disease from sharp injuries to health care workers Geneva, Switzerland. World Health Organization, 2003.

[10] Orji EO, Fasubaa OB, Onwudiegwu U, Hutin Z. Occupational health hazards among health care workers in an obstetrics and gynaecology unit of a Nigerian teaching hospital. J Obstet Gynaecol 2002;22(1):75-8.

[11] Accessed June 17, 2007

[12] Low DE, McGeer A: SARS - One year later. N Engl J Med 2003; 349:2381-2382

[13] Chaovavanich A, Wongsawat J, Dowell SF, et al: Early containment of severe acute respiratory syndrome
(SARS); experience from Bamrasnaradura Institute, T(UP)land. J Med Assoc T(UP) 2004; 87:1182-1187

[14] Booth TF, Kournikakis B, Bastien N, et al: Detection of airborne severe acute respiratory syndrome (SARS) coronavirus and environmental contamination in SARS outbreak units. J Infect Dis 2005; 191:1472-1477

[15] Cabana MD, Rand CS, Powe NR, et al: Why don't physicians follow clinical practice guidelines? A framework for improvement. JAMA 1999; 282:14581465

[16] Siegel JD, Rhinehart E, Jackson M, et al; Healthcare Infection Control Practices Advisory Committee. 2007 Guideline for Isolation Precautions: Preventing Transmi(UP)on of Infectious Agents in Healthcare Settings. Available at: http://www.cdc.gov/ncidod/dhqp/gl_isolation.html. Accessed June 27, 2007

[17] Pittet D, Simon A, Hugonnet S, et al: Hand hygiene among physicians: Performance, beliefs, and perceptions. Ann Intern Med 2004; 141:1-8

[18] O'Boyle CA, Henly SJ, Larson E: Understanding adherence to hand hygiene recommendations: The theory of planned behavior. Am J Infect Control 2001; 29:352-360

[19] Sax H, Uckay I, Richet H, et al: Determinants of good adherence to hand hygiene among healthcare workers who have extensive exposure to hand hygiene campaigns. Infect Control Hosp Epidemiol 2007; 28:1267-1274

[20] Berhe M, Edmond MB, Bearman GM: Practices and an assessment of healthcare workers' perceptions of compliance with infection control awarness of nosocomial infections. Am J Infect Control 2005; $33: 55-57$ 